\title{
Apatite U-Pb dating at UNAM laboratories: analytical protocols and examples of its application
}

\author{
Carlos Ortega-Obregón ${ }^{1, *}$, Fanis Abdullin ${ }^{2}$, Luigi Solari', \\ Peter Schaaf ${ }^{3}$, and Gabriela Solís-Pichardo ${ }^{4}$
}

\author{
${ }^{1}$ Centro de Geociencias, Universidad Nacional Autónoma de México, Campus Juriquilla, 76230 Querétaro, Qro., Mexico. \\ ${ }^{2}$ CONACyT - Universidad Nacional Autónoma de México, Campus Juriquilla, Centro de Geociencias, \\ Boulevard Juriquilla No. 3001, C.P. 76230, Juriquilla, Querétaro, Mexico. \\ ${ }^{3}$ Instituto de Geofísica, Universidad Nacional Autónoma de México, Ciudad Universitaria, 04510 Mexico City, Mexico. \\ ${ }^{4}$ Instituto de Geología, Universidad Nacional Autónoma de México, Ciudad Universitaria, 04510, Mexico City, Mexico. \\ *cortega@geociencias.unam.mx
}

\begin{abstract}
Apatite is the most common phosphate mineral in the Earth's crust and can be found in practically all magmatic and metamorphic rocks, as well as in ancient and recent sediments and in certain ore deposits. Its effective closure temperature of $450-550^{\circ} \mathrm{C}$ for the U-Pb system makes apatite an important natural medium-temperature thermochronometer that can be dated by both laser ablation inductively coupled plasma mass spectrometry (LA-ICP-MS) and isotope dilution thermal ionization mass spectrometry (ID-TIMS) techniques. Due to its low U content, coupled with high $\mathrm{Pb}$ contents incorporated during crystallization (also called common lead), apatite $\mathrm{U}-\mathrm{Pb}$ dating is analytically challenging, and requires robust analytical protocols to achieve reliable ages. In this experimental study we obtained apatite $\mathrm{U}-\mathrm{Pb}$ ages from six rock samples employing LA-ICP-MS (at Laboratorio de Estudios Isotópicos, Centro de Geociencias, UNAM), while one sample was also dated by ID-TIMS (at Laboratorio Universitario de Geoquímica Isotópica, UNAM). These samples have igneous emplacement or metamorphic ages broadly ranging from the Neoproterozoic to the Paleocene. The obtained apatite $\mathrm{U}-\mathrm{Pb}$ ages agree well with other radioisotopic data (U-Pb on zircon and K-Ar or Ar-Ar on micas and hornblende) available for the same rock samples tested, or for the same geological units studied. These apatite $\mathrm{U}-\mathrm{Pb}$ results, obtained for the first time at two main Mexican geochronology laboratories, are precise enough to be geologically meaningful and usually represent the cooling ages; though, in some cases they may also indicate the crystallization or the metamorphic age. Some advantages and disadvantages of LA-ICPMS- and ID-TIMS-based methodologies were observed and outlined. Our results validate the analytical procedures used and will serve as an important trigger towards the development or improvement of medium-temperature thermochronology techniques in Mexico.
\end{abstract}

Key words: apatite; laser ablation, isotope dilution; $\mathrm{U}-\mathrm{Pb}$ dating; thermochronology; Mexico.

\section{RESUMEN}

El apatito es el mineral de fosfato más común en la corteza de la Tierra y puede encontrarse en casi todas las rocas magmáticas y metamórficas, así como en algunos sedimentos antiguos y recientes $y$ en ciertos depósitos minerales. La temperatura de cierre efectiva de 450-550 ${ }^{\circ} \mathrm{C}$ para el sistema $U-P b$ hace que el apatito sea un importante termocronómetro natural de temperatura media, el cual se puede fechar tanto por la técnica de ablación láser asociada a un espectrómetro de masas con fuente de plasma de acoplamiento inductivo (LA-ICP$M S$, por sus siglas en inglés) como por el método de dilución isotópica usando espectrometría de masas con ionización térmica (ID-TIMS, por sus siglas en inglés). Debido a su bajo contenido de $U$, aunado a un alto contenido de plomo incorporado durante la cristalización (denominado también plomo común), la datación $\mathrm{U}-\mathrm{Pb}$ en apatitos es un proceso retador que requiere protocolos analíticos robustos para obtener edades confiables. En este estudio experimental hemos obtenido edades $\mathrm{U}-\mathrm{Pb}$ en apatitos de seis muestras analizadas por LA-ICPMS en el Laboratorio de Estudios Isotópicos, Centro de Geociencias, UNAM, así como en una muestra mediante ID-TIMS en el Laboratorio Universitario de Geoquímica Isotópica, UNAM. Estas muestras tienen edades ígneas o de metamorfismo que varían en un rango amplio, desde el Neoproterozoico hasta el Paleoceno. Las edades $\mathrm{U}-\mathrm{Pb}$ determinadas en apatitos concuerdan bien con otros datos radioisotópicos (e.g., U-Pb en circones y K-Ar y Ar-Ar en micas y hornblenda) disponibles para las mismas muestras de roca analizadas, o para las mismas unidades geológicas estudiadas. Las edades $\mathrm{U}-\mathrm{Pb}$ de apatitos, obtenidas por primera vez en dos principales laboratorios mexicanos de geocronología, son suficientemente precisas para tener algún sentido geológico e indican usualmente las edades de enfriamiento (tres muestras), aunque en algunos casos pueden señalar también las edades de cristalización o de metamorfismo. Algunas ventajas $y$ desventajas entre las metodologías basadas en LA-ICP-MS e ID-TIMS fueron también observadas y señaladas. Los resultados de este estudio 
validan los procedimientos analíticos utilizados y servirán como un inicio importante hacia el desarrollo o mejoramiento de las técnicas de termocronología de media temperatura en México.

Palabras clave: apatito; ablación láser; dilución isotópica; datación U-Pb; termocronología; México.

\section{INTRODUCTION}

Apatite, the most common phosphate mineral with typical natural occurrence as $\mathrm{Ca}_{5}\left(\mathrm{PO}_{4}\right)_{3}[\mathrm{~F}, \mathrm{Cl}, \mathrm{OH}]$, has attracted great interest as a low- and medium-temperature thermochronometer (fission-track analysis, $\mathrm{U}(\mathrm{Th}) / \mathrm{He}$ and $\mathrm{U}-\mathrm{Pb}$ dating; e.g., Wolf et al., 1996; Ehlers and Farley, 2003; Hasebe et al., 2004; Donelick et al., 2005; Solé and Pi, 2005; Chew and Donelick, 2012; Abdullin et al., 2014; Chew et al., 2014; Enkelmann et al., 2014; Spikings et al., 2015); as a chemical indicator of petrogenetic or metallogenetic processes, as well as a novel geochemical tool in sedimentary provenance studies (Belousova et al., 2002; Morton and Yaxley, 2007; Jafarzadeh et al., 2014; Abdullin et al., 2016a and 2016b; Bruand et al., 2016); or even as an isotopic tracer (e.g., Sr isotopes, assuming that apatite does not incorporate any significant amount of initial Rb; Bizzarro et al., 2003); or as a proxy of the redox state of silicic host magmas as well (Miles et al., 2014).

On the other hand, zircon $\left(\mathrm{ZrSiO}_{4}\right)$ is still the most commonly used $\mathrm{U}$-rich accessory mineral in $\mathrm{U}-\mathrm{Pb}$ dating. Its high closure temperature for this isotopic system, greater than $800^{\circ} \mathrm{C}$, as well as its exceptional chemical and mechanical robustness (e.g., Lee et al., 1997; Cherniak and Watson, 2001) allow robust igneous crystallization ages and ages of medium- to high-grade metamorphism to be obtained, as well as to extract provenance signals from siliciclastic samples (e.g., Krogh, 1982; Košler et al., 2002; Jackson et al., 2004; Weber et al., 2005, 2007, 2008; Solari et al., 2014, 2015).

While zircon is relatively straightforward to date by the U-Pb method (e.g., see Faure and Mensing, 2005; Schoene, 2014; Solari et al., 2015), apatite $\mathrm{U}-\mathrm{Pb}$ dating is more challenging. The main issues of dating accessory minerals by LA-ICP-MS that could have incorporated $\mathrm{Pb}$ during crystallization are listed and described by Chew et al. (2014). In the case of apatite, the issues lie in the low $U$ concentration that generally vary from 1 to $50 \mathrm{ppm}$; though, in some cases these values may be increased up to 100-300 ppm (for instance, in apatite of sample Congra-2; see details below), while apatite may incorporate high levels of lead during the magma crystallization (hereafter referred to as common $\mathrm{Pb}$ ) (Chamberlain and Bowring, 2001; Schoene and Bowring, 2007; Chew et al., 2011, 2014; Thomson et al., 2012).

Another issue for apatite $\mathrm{U}-\mathrm{Pb}$ dating, in particular by microanalytical instruments like LA-ICP-MS, is the lack of isotopically homogeneous and large natural apatite crystals to be used as a primary reference material. There are numerous standard zircons (Horstwood et al., 2016, and references therein); meanwhile, the few apatite U-Pb standards can contain variable amounts of common $\mathrm{Pb}$, which makes the $\mathrm{U}-\mathrm{Pb}$ isotope ratio calculation more complex than for zircons (Chew et al., 2011; Thomson et al., 2012; Chew et al., 2014). However, this can be corrected by applying a ${ }^{207} \mathrm{~Pb}$-based correction depending on the initial ${ }^{207} \mathrm{~Pb} /{ }^{206} \mathrm{~Pb}$ value of the standard apatite (Chew et al., 2014; see section "LA-ICP-MS technique (LEI)" below). Ionic diffusion of radioactive and/or daughter isotopes of any geochronological system in crystal structures are assumed as dependent of ambient temperature and cooling rate, and it defines the closure temperature (e.g., Dodson, 1973; Copeland et al., 1988; Villa, 1988). Apatite U-Pb is a useful thermochronometer due to the following reasons: (1) Apatite is a common accessory mineral in virtually all igneous lithologies, and it is also a common component of many metamorphic and siliciclastic and some non-clastic sedimentary rocks, as well as of certain ore deposits (e.g., Green and Watson, 1982; Piccoli and Candela, 2002; Morton and Yaxley, 2007; Webster and Piccoli, 2015); (2) its effective closure temperature of $c a .450$ to $550{ }^{\circ} \mathrm{C}$ for $\mathrm{U}-\mathrm{Pb}$, together with its partial retention zone of radiogenic lead (PbPRZ) of $\sim 370-580{ }^{\circ} \mathrm{C}$ (Cherniak et al., 1991; Chamberlain and Bowring, 2001; Schoene and Bowring, 2007; Cochrane et al., 2014), makes apatite U-Pb dating a new, alternative technique to obtain crystallization ages (i.e., of rapidly cooled shallow intrusions, volcanic and subvolcanic rocks), ages of metamorphism (Henrichs et al., 2018) and of hydrothermal or mineralization processes, as well as to construct thermal histories of crystalline basement, among others; and, (3) apatite is seemingly stable during sediment transport and is extremely stable during diagenesis preserving its original composition (Morton and Hallsworth, 2007; Morton and Yaxley, 2007), which may be particularly useful for sedimentary provenance studies and to obtain approximate stratigraphic ages based on detrital apatite U-Pb results (Chew and Donelick, 2012; O'Sullivan et al., 2016; Bedoya et al., 2017).

In this experimental study, we report the first apatite $\mathrm{U}-\mathrm{Pb}$ results obtained in Mexican geochronology laboratories, testing this technique on different igneous and metamorphic rocks, which have already been dated by conventional radioisotopic methods like $\mathrm{U}-\mathrm{Pb}$ on zircons, and K-Ar or Ar-Ar dating. The chosen samples have crystallization or metamorphic ages ranging from the Mesoproterozoic to the Paleocene (for more details see Table 1). Our U-Pb results on apatite validate the used analytical procedures and will serve as a starting point for the development or improvement of medium-temperature thermochronology techniques in Mexico.

\section{DESCRIPTION OF SAMPLES}

\section{Sample Congra-2}

Congra-2 is a monzogranite from the southern Sierra Madre Occidental. For its cognate sample, collected from the same plutonic body, an emplacement age of $59.4 \pm 0.5(2 \sigma)$ Ma was proposed on the basis of zircon $\mathrm{U}-\mathrm{Pb}$ results (Sample Conc-01 in Duque-Trujillo et al., 2014). Hornblende and biotite concentrates from Conc-01 yielded Ar-Ar ages at $55.7 \pm 0.5(2 \sigma)$ and $56.3 \pm 0.3(2 \sigma)$ Ma, respectively, both cooling ages that were also obtained by Duque-Trujillo et al. (2014).

\section{Sample OV-0421}

This sample is a two mica-bearing deformed granite belonging to the Tres Sabanas pluton, which is located NW of Guatemala City, Guatemala. Torres de León (2016) reported a U-Pb zircon age of $115 \pm$ $4 \mathrm{Ma}(2 \sigma)$ for OV-0421, interpreted as its crystallization age. A cooling age of $102.2 \pm 1.2(2 \sigma) \mathrm{Ma}$, obtained by the K-Ar method, has also been reported by the same author.

\section{Sample MCH-40}

$\mathrm{MCH}-40$ is an andesite of rather hypabyssal origin. This rock was sampled to the east of Jacinto Tirado town, Chiapas (Table 1) from an Early to Middle (?) Jurassic volcanic unit named informally as Andesita Pueblo Viejo (e.g., Castro-Mora et al., 1975; Meneses-Rocha, 2001; Godínez-Urban et al., 2011). Due to its age uncertainty, MCH-40 was also dated by zircon $\mathrm{U}-\mathrm{Pb}$ technique (see details below).

\section{Sample MCH-17}

This rock sample is a metamorphosed granite, collected from the Chiapas Massif near the Cintalapa de Figueroa town. According to several authors (e.g., Damon et al., 1981; Torres et al., 1999; Meneses- 
Table 1. Lithology, locality, and previously published geochronological data of selected samples.

\begin{tabular}{|c|c|c|c|c|c|c|}
\hline \multirow[t]{2}{*}{ Sample } & \multirow[t]{2}{*}{ Locality } & \multirow[t]{2}{*}{ Lithology } & \multicolumn{3}{|c|}{ Published geochronological data } & \multirow[t]{2}{*}{ Notes } \\
\hline & & & Age (Ma) & $\pm 2 \mathrm{~s}$ (abs) & MSWD & \\
\hline \multirow[t]{3}{*}{$\begin{array}{l}\text { Congra-2 } \\
\text { (Conc-01) }\end{array}$} & \multirow[t]{3}{*}{$\begin{array}{l}\text { Concordia, Sinaloa } \\
\left(23^{\circ} 16^{2} 21.0^{\prime \prime} \mathrm{N} ; 106^{\circ} 07^{\prime} 01.6^{\prime \prime} \mathrm{W}\right)\end{array}$} & \multirow[t]{3}{*}{$\begin{array}{l}\text { Monzogranite } \\
\text { (undeformed) }\end{array}$} & 59.4 & 0.5 & \multirow[t]{3}{*}{0.79} & $\begin{array}{l}\text { Average }{ }^{206} \mathrm{~Pb} /{ }^{238} \mathrm{U} \text { zircon age; } \mathrm{n}=30 \text { (Duque-Trujillo et al., } 2014 . \\
\text { sample Conc-01). }\end{array}$ \\
\hline & & & 55.7 & 0.5 & & Ar-Ar hornblende age (Duque-Trujillo et al., 2014). \\
\hline & & & 56.3 & 0.3 & & Ar-Ar biotite age (Duque-Trujillo et al., 2014). \\
\hline \multirow[t]{2}{*}{ OV-0421 } & \multirow{2}{*}{$\begin{array}{l}\text { Central Guatemala } \\
\left(14^{\circ} 46^{\prime} 29.3^{\prime \prime} \mathrm{N} ; 90^{\circ} 33^{\prime} 08.0^{\prime \prime} \mathrm{W}\right)\end{array}$} & \multirow[t]{2}{*}{ Deformed granite } & 115 & 4 & & Average ${ }^{206} \mathrm{~Pb} /{ }^{238} \mathrm{U}$ zircon age; $\mathrm{n}=16$ (Torres de León, 2016). \\
\hline & & & 102.2 & 1.2 & & K-Ar biotite age (Torres de León, 2016). \\
\hline $\mathrm{MCH}-40$ & $\begin{array}{l}\text { Chiapas } \\
\left(16^{\circ} 43^{\prime} 04.0^{\prime \prime} \mathrm{N} ; 93^{\circ} 45^{\prime} 33.0^{\prime \prime} \mathrm{W}\right)\end{array}$ & Andesitic dike & & & & Average ${ }^{206} \mathrm{~Pb} /{ }^{238} \mathrm{U}$ zircon age; $\mathrm{n}=27$ (this work; see results). \\
\hline $\mathrm{MCH}-17$ & $\begin{array}{l}\text { Chiapas } \\
\left(16^{\circ} 24^{\prime} 46.0^{\prime \prime} \mathrm{N} ; 93^{\circ} 47^{\prime} 42.0^{\prime \prime} \mathrm{W}\right)\end{array}$ & Metagranite & & & & $\begin{array}{l}\text { Average }{ }^{206} \mathrm{~Pb} /{ }^{238} \mathrm{U} \text { zircon age; } \mathrm{n}=25 \text { (this work; see results) } \\
\text { ID-TIMS leached apatite age (this work; see results). }\end{array}$ \\
\hline Gt-0340 & $\begin{array}{l}\text { Rabinal, Guatemala } \\
\left(15^{\circ} 06^{\prime} 39.0^{\prime \prime} \mathrm{N} ; 90^{\circ} 30^{\prime} 02.0^{\prime \prime} \mathrm{W}\right)\end{array}$ & Deformed granite & 483 & 7 & & $\begin{array}{l}\text { ID-TIMS lower intercept zircon age (Ortega-Obregón et al., } \\
\text { 2008). }\end{array}$ \\
\hline OC111 & $\begin{array}{l}\text { Oaxaca } \\
\left(18^{\circ} 05^{\prime} 31.4^{\prime \prime} \mathrm{N} ; 97^{\circ} 20^{\prime} 21.0^{\prime \prime} \mathrm{W}\right)\end{array}$ & Ortogneiss & 990 & 10 & & Average ${ }^{206} \mathrm{~Pb} /{ }^{238} \mathrm{U}$ zircon age; $\mathrm{n}=25$ (Solari et al., 2014). \\
\hline
\end{tabular}

Rocha, 2001; Schaaf et al., 2002; Weber et al., 2005), the Chiapas Massif is a Permian-Triassic continental arc and represents the basement of the southern Maya block. This unit is mainly composed of diverse plutonic rocks, most of which are deformed while some are metamorphosed. To better constrain its crystallization age, zircons from $\mathrm{MCH}-17$ were also dated in the current work by employing LA-ICP-MS-based U-Pb method. This sample is the only one from which apatite were analyzed by both LA-ICP-MS and ID-TIMS techniques. This was done mainly to evaluate the $\mathrm{U}-\mathrm{Pb}$ results obtained by two different analytical methods and to see eventual discrepancies (details in "Analytical Methods" section).

\section{Sample GT-0340}

This sample belongs to the undeformed Rabinal Granite, cropping out north from the Rabinal town in Baja Verapaz, Guatemala. Many zircon aliquots from GT-0340 were previously dated by U-Pb ID-TIMS, yielding an age of $482.6 \pm 7(2 \sigma) \mathrm{Ma}$ (Concordia upper intercept) that was interpreted as its approximate crystallization age (Ortega-Obregón et al., 2008). This age is similar to others obtained in different samples from the same granite (e.g., Solari et al., 2013).

\section{Sample OC-111}

This sample is a granulitic gneiss from the Grenville-aged Oaxacan Complex. The sample is composed by quartz, mesoperthite, rutile, garnet, and by altered mafic minerals. OC-111 was sampled $c a .120$ $\mathrm{km}$ north of Oaxaca City, to the east of the tectonic contact between the Zapoteco and Mixteco tectonostratigraphic terrains (e.g., see ElíasHerrera et al., 2007). Previous U-Pb zircon dating yielded protolith crystallization ages at $\sim 1220 \mathrm{Ma}$, although it was also demonstrated that this sample underwent "dry" granulite facies metamorphism at $990 \pm 10 \mathrm{Ma}$ (Solari et al., 2014).

\section{ANALYTICAL METHODS}

Apatite U-Pb analyses were performed by a joint effort between the Laboratorio Universitario de Geoquímica Isotópica (LUGIS, Instituto de Geofísica, CDMX, UNAM) and the Laboratorio de Estudios Isotópicos (LEI, Centro de Geociencias, Campus Juriquilla, UNAM). Apatite U-Pb dating at LUGIS was based on ID-TIMS technique, while in LEI all the six selected samples were analyzed with LA-ICP-MS.

\section{Preparation of samples}

Sample preparation was performed at the Centro de Geociencias (Taller de Molienda and Taller de Laminación), Campus Juriquilla, UNAM. Heavy minerals were concentrated from two narrow grain-size fractions of $63-125$ and $125-180 \mu \mathrm{m}$, using conventional methods/ instruments like crushing, sieving, Wilfley ${ }^{\mathrm{TM}}$ table, Frantz ${ }^{\mathrm{TM}}$ separator, and finally by hand-picking under a binocular microscope. For U-Pb dating by ID-TIMS, only 'sterile' apatite grains, without visible inclusions and other defects like cracks, were selected to be split into two aliquots with $\sim 300$ crystals of different size and morphology (e.g., see Figure 1). Analysis by ID-TIMS was performed only for sample $\mathrm{MCH}$ 17. For LA-ICP-MS-based apatite U-Pb dating, 200 apatite crystals extracted from each sample were mounted with EpoFix ${ }^{\mathrm{TM}}$ Struers in a $2.5 \mathrm{~cm}$ diameter plastic ring, and then polished with Buehler $\mathrm{SiC}$ MicroCut ${ }^{\mathrm{TM}}$ sandpapers P1500 $(\sim 12.5 \mu \mathrm{m})$ and P2500 $(\sim 8.3 \mu \mathrm{m})$, and alumina suspensions over Buehler MicroCloth ${ }^{\mathrm{TM}}$ pads (see an example illustrated on Figure 2). LA-ICP-MS analyses were performed for all the six selected samples. In addition, two samples (MCH-17 and $\mathrm{MCH}-40)$ were also prepared for zircon U-Pb dating, from which $\mathrm{ca}$. 100 crystals from each sample were mounted to be analyzed by LA-ICP-MS.

\section{ID-TIMS methodology (LUGIS)}

An additional observation of the selected apatite crystals using a binocular microscope, cleaning, chemical treatments, and isotopic measurements were entirely carried out at LUGIS. One of the two aliquots with $\sim 300$ apatite crystals was leached in $0.25 \mathrm{M} \mathrm{HNO}_{3}$ at ambient temperature $\left(24^{\circ} \mathrm{C}\right)$ for $1 \mathrm{~min}$ to remove any non-radiogenic $\mathrm{Pb}$ from their exterior surface, and then rinsed with de-ionized water. The other one, also made up of 300 crystals, was cleaned only in Milli-Q water. The aliquots were dried down, transferred into Teflon ${ }^{\mathrm{TM}}$ microcapsules and weighted, then $1 \mathrm{ml}$ of ultrapure $8 \mathrm{M} \mathrm{HNO}_{3}$ was added. The complete digestion of both aliquots (i.e., leached and non-leached) was performed at $110^{\circ} \mathrm{C}$ for 20 hours; then, the solutions were dried down. After evaporation, a drop of $6 \mathrm{M} \mathrm{HCl}$ was added and dried to convert the produced components to chlorides. The dry residues derived from both aliquots were dissolved in $600 \mu \mathrm{l}$ of $3 \mathrm{M} \mathrm{HCl}$, and heated at $110^{\circ} \mathrm{C}$ for 7 hours. Each digested aliquot was split into two fractions; one for isotopic composition (IC) analyses, and a second for isotope dilution (ID) measurements to which a mixed ${ }^{208} \mathrm{~Pb}-{ }^{238} \mathrm{U}$ spike was added. $\mathrm{U}$ and $\mathrm{Pb}$ were separated by chromatographic column chemistry technique employing BioRad ${ }^{\mathrm{TM}}$ AG-1X8 resins within Teflon ${ }^{\mathrm{TM}}$ columns. 

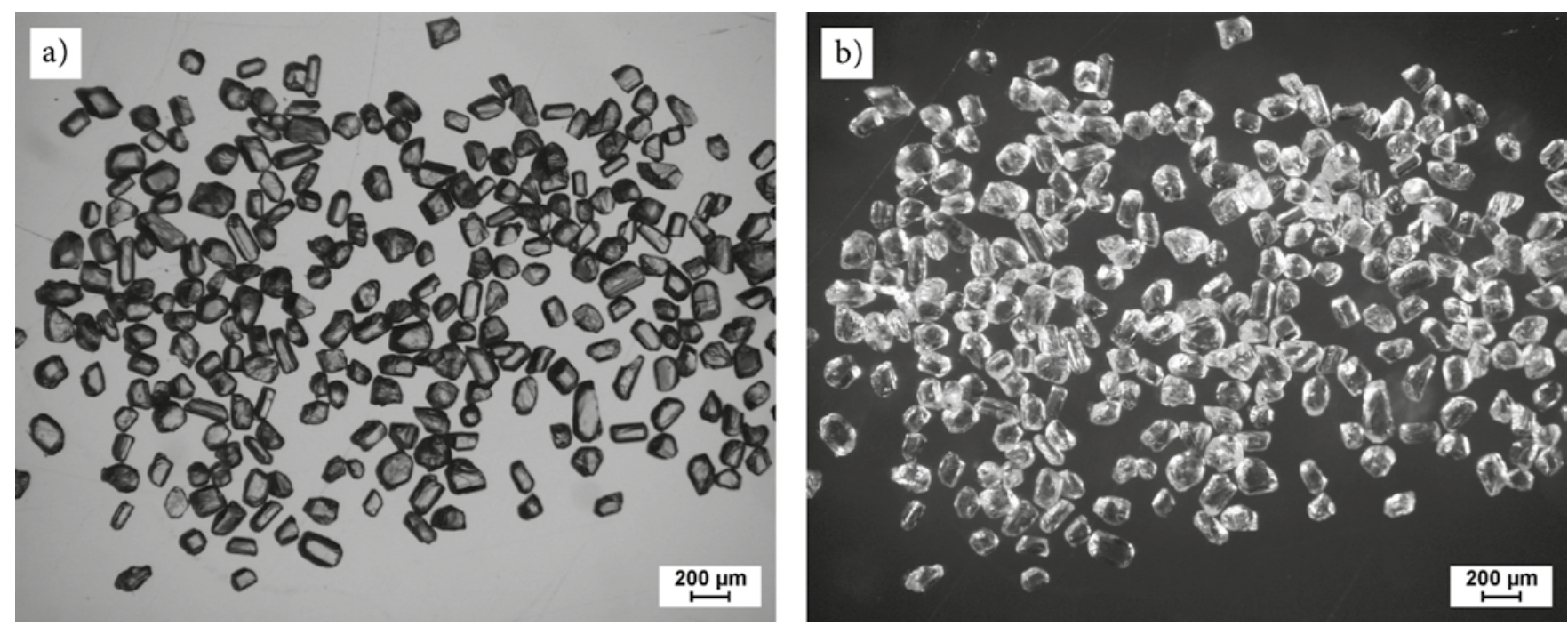

Figure 1. Photomicrograph of selected apatite crystals for ID-TIMS analysis from sample MCH-17 using (a) transmitted and (b) reflected light. Note that most of crystals are free of inclusions or fractures.

The prepared samples were loaded on Re filaments with the addition of a silica gel- $\mathrm{H}_{3} \mathrm{PO}_{4}$ mixture and analyzed in static mode. $\mathrm{Pb}$ isotopic measurements were performed in a Thermo ${ }^{\mathrm{TM}}$ TRITON Plus mass spectrometer; measuring ${ }^{204} \mathrm{~Pb}$ with an ion counter, whereas the remaining $\mathrm{Pb}$ isotopes $\left({ }^{206} \mathrm{~Pb},{ }^{207} \mathrm{~Pb}\right.$, and ${ }^{208} \mathrm{~Pb}$ ) were measured in Faraday cups. U concentrations were determined with a Finnigan ${ }^{\mathrm{TM}}$ MAT-262 mass spectrometer. Finally, 30 and 45 isotope ratios were acquired for $\mathrm{U}$ and $\mathrm{Pb}$, respectively. Mass fractionation was taken into account based on PbDat v. 1.24 (Ludwig, 1993) and applying a correction factor of $0.12 \%$ for each isotopic pair $\left({ }^{206} \mathrm{~Pb} /{ }^{204} \mathrm{~Pb},{ }^{206} \mathrm{~Pb} /{ }^{207} \mathrm{~Pb}\right.$, and $\left.{ }^{206} \mathrm{~Pb} /{ }^{208} \mathrm{~Pb}\right)$. The values for initial common $\mathrm{Pb}$ were estimated at $250 \mathrm{Ma}$ (Permian-Triassic Chiapas Massif; Damon et al., 1981; Schaaf et al., 2002; Weber et al., 2005), following the well-accepted methodology of Stacey and Kramers (1975). During the experiment at LUGIS, total analytical blanks for $\mathrm{Pb}$ and $\mathrm{U}$ were obtained as 18 and $16 \mathrm{pg}$, respectively. However, in further experiments these values may change, and thus, will have to be carefully controlled again.

\section{LA-ICP-MS technique (LEI)}

Spot analyses were performed with a Resonetics RESOlution ${ }^{\mathrm{TM}} \mathrm{LPX}$ Pro (193 nm, ArF excimer) laser ablation system, coupled to a Thermo Scientific iCAP ${ }^{\mathrm{TM}}$ Qc quadrupole ICP-MS at LEI. Different analytical protocols were employed for zircon and apatite. For zircon, each spot analysis consisted in the acquisition of $15 \mathrm{~s}$ of background signal (gas blank), $30 \mathrm{~s}$ of ablation, and $15 \mathrm{~s}$ to allow the signal to reach the baseline again (wash-out). The spot diameter was of $23 \mu \mathrm{m}$, using a fluence of $6 \mathrm{~J} / \mathrm{cm}^{2}$ with a repetition rate of $5 \mathrm{~Hz}$. For apatite, $35 \mathrm{~s}$ of ablation was chosen with the same gas blank and wash-out acquisition times as given above. In this case, a spot of $60 \mu \mathrm{m}$ was employed, basically to obtain a larger volume of the ablated material to be analyzed with the purpose of compensate for weaker signals of $\mathrm{U}$ and $\mathrm{Pb}$. Due to different coupling of laser energy in different materials, the laser pulse energy and repetition rate were reduced to $4 \mathrm{~J} / \mathrm{cm}^{2}$ and $4 \mathrm{~Hz}$, respectively. For both zircon and apatite, $350 \mathrm{ml} / \mathrm{min}$ of He was used as a carrier gas, mixed in the cell with $c a .800 \mathrm{ml} / \mathrm{min}$ of Ar. Four and three $\mathrm{ml} / \mathrm{min}$ of $\mathrm{N}_{2}$ for zircon and
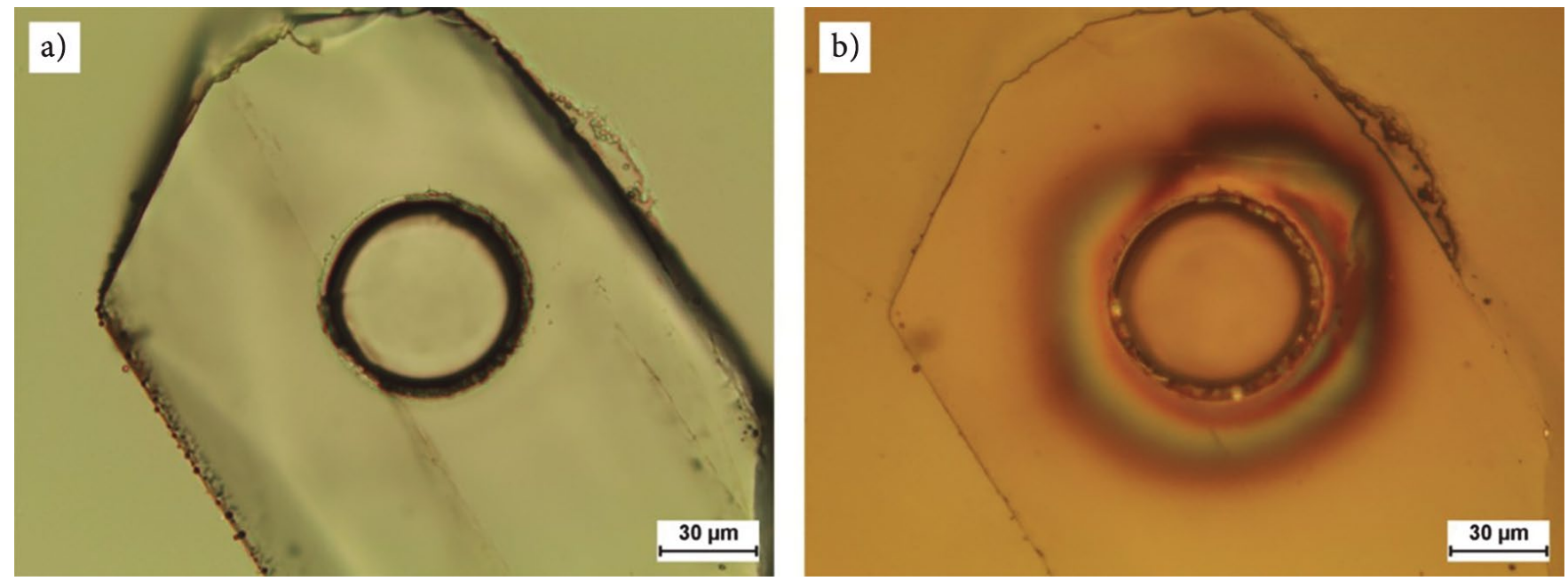

Figure 2. Photomicrograph of an apatite crystal after ablation in (a) transmitted and (b) reflected light. Spot diameter (center of the crystal) is $60 \mu \mathrm{m}$. The selected crystals for LA-ICP-MS analysis are free of inclusions or cracks. Note the concentric deposits of ablated material around the crater in reflected light (b). 
apatite analyses were also added after the cell, respectively, to increase the sensitivity of the plasma. A "squid" signal homogenizer is located right after the ablation cell, to mix properly all the gases added before reaching the plasma. Single-spot analyses in apatite were performed in inclusion-free grains or in those parts in which no visible inclusion or other defects were present (e.g., see in Figure 2).

Together with those isotopes needed for the $\mathrm{U}-\mathrm{Pb}$ age calculation $\left({ }^{206} \mathrm{~Pb},{ }^{207} \mathrm{~Pb},{ }^{208} \mathrm{~Pb},{ }^{232} \mathrm{Th}\right.$, and $\left.{ }^{238} \mathrm{U}\right)$, LA-ICP-MS permits to sequentially detect additional elements such as REE (rare earth elements, La to Lu), $\mathrm{Sr}, \mathrm{Y}, \mathrm{Mn}, \mathrm{Mg}, \mathrm{Cl}$, etc. These detailed chemical compositions are not shown because they are beyond the scope of this paper. This protocol for apatite analyses was established on the basis of numerous experiments carried out at the LEI Lab during the past years, and may be used for simultaneous $\mathrm{U}-\mathrm{Pb}$ and fission-track in-situ double dating plus multielemental analysis (e.g. Abdullin et al., 2016a and 2016b).

Tuning of the ICP-MS followed the parameters reported in Solari et al. (2010) and Ortega-Obregón et al. (2014). Corrected isotope ratios, ages and errors were calculated using Iolite software (Paton et al., 2011) and the VizualAge data reduction scheme of Petrus and Kamber (2012). The standard zircon "91500" (Wiedenbeck et al., 1995, 2004) was used as a reference mineral for zircon U-Pb analyses. In the course of this experiment, an age of $337.7 \pm 1.5(2 \sigma)$ Ma was obtained for the Plešovice zircon used as a secondary standard for zircon $\mathrm{U}-\mathrm{Pb}$ analyses, yielding a mean square weighted deviation (MSWD) of 1.2 from 20 single-spot $\mathrm{U}-\mathrm{Pb}$ ages. This value is in line with the standard ${ }^{206} \mathrm{~Pb} /{ }^{238} \mathrm{U}$ age of $\mathrm{ca} .337 \mathrm{Ma}$ (Sláma et al., 2008).

In the case of apatite U-Pb dating, UcomPbine (Chew et al., 2014) was used to model ${ }^{207} \mathrm{~Pb} /{ }^{206} \mathrm{~Pb}$ initial values and thus force $\mathrm{a}{ }^{207} \mathrm{~Pb}$ correction that considers the common $\mathrm{Pb}$ incorporated by apatite standards at the moment of their crystallization. As is described by Chew et al. (2014), this correction is applied immediately after baseline subtraction and previously to the "raw" standard ratios calculation in order to not compromise down-hole fractionation and mass bias corrections. Once the standard is corrected and down-hole fractionation modeled, the drift in the mass discrimination during a session is subsequently accounted by sample-standard bracketing. Tera and Wasserburg $(\mathrm{T}-\mathrm{W})$ Concordia diagrams are commonly used in apatite $\mathrm{U}-\mathrm{Pb}$ dating, because results are mostly discordant. The lower intercept in $\mathrm{T}-\mathrm{W}$, is considered as a "mean" apatite $\mathrm{U}-\mathrm{Pb}$ age that should have geological significance (e.g., crystallization or cooling age, or the age of a metamorphic event).

For apatite $\mathrm{U}-\mathrm{Pb}$ dating, the Madagascar apatite was used as a main reference material (with a mean $\mathrm{U}-\mathrm{Pb}$ age of $485-475 \mathrm{Ma}$; Thomson et al., 2012; Chew et al., 2014), assuming that matching of the matrix is fundamental during the U-Pb dating by LA-ICP-MS (e.g., Gehrels et al., 2008; Solari et al., 2010, 2015).

Due to limitations in the LEI Lab, no representative and wellstudied secondary $\mathrm{U}-\mathrm{Pb}$ standard was used for apatite $\mathrm{U}-\mathrm{Pb}$ dating. However, as was mentioned above, the sample $\mathrm{MCH}-17$ was chosen to be dated by both ID-TIMS and LA-ICP-MS techniques. This sample, thus, was also used to control the final U-Pb ages obtained for all the apatite samples selected (see results below). Age and error calculations, including zircon mean ages and intercept values and uncertainties, were carried out using Isoplot v. 3.7, written by Ludwig (2008).

\section{RESULTS AND INTERPRETATIONS}

\section{Zircon $\mathrm{U}-\mathrm{Pb}$ ages}

Zircons from two of the six experimental samples (MCH-17 and $\mathrm{MCH}-40$ ) were dated by U-Pb employing LA-ICP-MS (LEI; U-Pb results are detailed in Figure 3 and Supplementary Appendix A1). Only results within - 5 to $30 \%$ of concordance were considered as reliable ages. Weighted average ages were calculated using Isoplot v. 4.15 (Ludwig, 2008 ) rejecting outliers (less than $95 \%$ of confidence).

\section{Sample $\mathrm{MCH}-17$}

MCH-17 mainly contains prismatic and bipyramidal zircon crystals, most of which are larger than 100-150 $\mu \mathrm{m}$ length and $50-100 \mu \mathrm{m}$ width. A detailed observation of their morphology suggests that these crystals are of igneous origin, without evidence from cathodoluminescence of possible metamorphic rims. From a total of 35 zircons dated, 27 passed the concordance filters (those within -5 to $30 \%$ of discordance) and were considered meaningful for the interpretation of the igneous crystallization age. The remaining analyses are concordant to slightly discordant (see Supplementary Appendix A1), and define a marked cluster between $\sim 260$ and $\sim 250 \mathrm{Ma}$ in the Concordia diagram (Figure $3 \mathrm{a}$ ). The mean ${ }^{206} \mathrm{~Pb} /{ }^{238} \mathrm{U}$ age of $253 \pm 2.5(2 \sigma) \mathrm{Ma}$, displayed in Figure $3 \mathrm{~b}$, can be interpreted as the best approximation for the crystallization age of this granitic sample.

\section{Sample MCH-40}

Most zircon grains from the andesite sample MCH- 40 are small (50-100 $\mu \mathrm{m}$ long, 30-60 $\mu \mathrm{m}$ wide) with poorly developed prism facets and pyramids. 35 zircon crystals were analyzed, 27 of which are considered reliable for age interpretation. The $\mathrm{U}-\mathrm{Pb}$ ages are concordant and straddle the Concordia curve at $195 \mathrm{Ma}$ (lower Sinemurian age; Figure $3 \mathrm{~d}$ ). The mean ${ }^{206} \mathrm{~Pb} /{ }^{238} \mathrm{U}$ age of $196.1 \pm 1.5(2 \sigma) \mathrm{Ma}$ is, hence, interpreted as the best crystallization age for $\mathrm{MCH}-40$ (Figure $3 \mathrm{~d}$ ).

\section{Apatite $\mathrm{U}-\mathrm{Pb}$ ages}

Apatite $\mathrm{U}-\mathrm{Pb}$ results obtained from all the six studied rock samples are described below. Detailed information on our LA-ICP-MS U-Pb experiments is given in Supplementary Appendix A2.

\section{Sample Congra-2}

Apatite from the youngest sample Congra-2 show a well-defined linear regression in the $\mathrm{T}-\mathrm{W}$ diagram, which is derived from all the 34 single-spot analyses performed with LA-ICP-MS. A lower intercept age of $60.9 \pm 1.5(2 \sigma)$ Ma was detected $(M S W D=0.95$; Figure $4 a)$. Despite its young age (Paleocene; Duque-Trujillo et al., 2014), a statistically very reliable apatite $\mathrm{U}-\mathrm{Pb}$ age was obtained for Congra-2, which is also supported by a MSWD that is close to 1 . This is due to high $U$ contents that vary broadly from one apatite to another (31.1 to $371.5 \mathrm{ppm}$ with a mean of $108.2 \mathrm{ppm}$, standard deviation $(\mathrm{SD})=69.5$; Supplementary Appendix A2), which was crucial to yield strongly heterogeneous isotopic ratios for the $\mathrm{U}-\mathrm{Pb}$ system as well as to generate high levels of radiogenic $\mathrm{Pb}$, and thus displaying a perfect order on the Discordia line (Figure $4 \mathrm{a}$ ) with a very low age error (only $2.5 \%$ at $2 \sigma$ level).

This pluton yielded a crystallization age of $59.4 \pm 0.5(2 \sigma) \mathrm{Ma}$ as it was well documented by zircon U-Pb geochronology, and then cooled to $\sim 56 \mathrm{Ma}$ as suggested by Ar-Ar ages in hornblende and biotite (Sample Conc-01; Duque-Trujillo et al., 2014). In this case, the apatite lower intercept $\mathrm{U}-\mathrm{Pb}$ age of $60.9 \pm 1.5(2 \sigma) \mathrm{Ma}$ is within the analytical uncertainty of the zircon age, therefore, this apatite $\mathrm{U}-\mathrm{Pb}$ date also seems to indicate the igneous crystallization age for Congra-2 (Conc01 ), suggesting that the pluton was likely emplaced at a temperature above the Ar-Ar closure temperature of hornblende and biotite, and lower than the closure temperature of the apatite $\mathrm{U}-\mathrm{Pb}$ system.

\section{Sample OV-0421}

For the Tres Sabanas granite OV-0421, the lower intercept in T-W yielded an apatite $\mathrm{U}-\mathrm{Pb}$ date of $106.7 \pm 8.7(2 \sigma) \mathrm{Ma}$, obtained from 42 spots (Figure $4 \mathrm{~b}$ ). These apatites have $\mathrm{U}$ contents of $84-177 \mathrm{ppm}$ with 

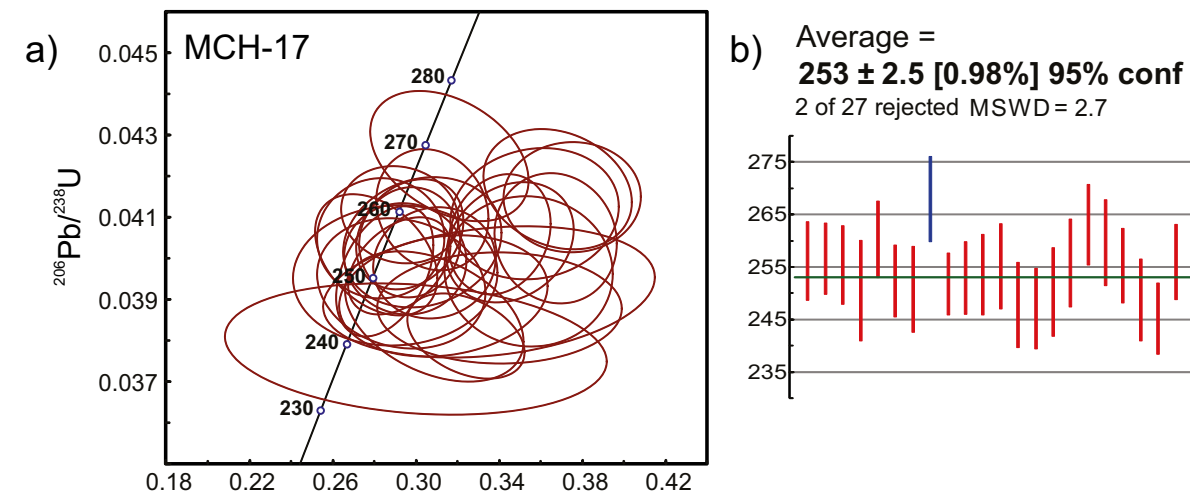

C)
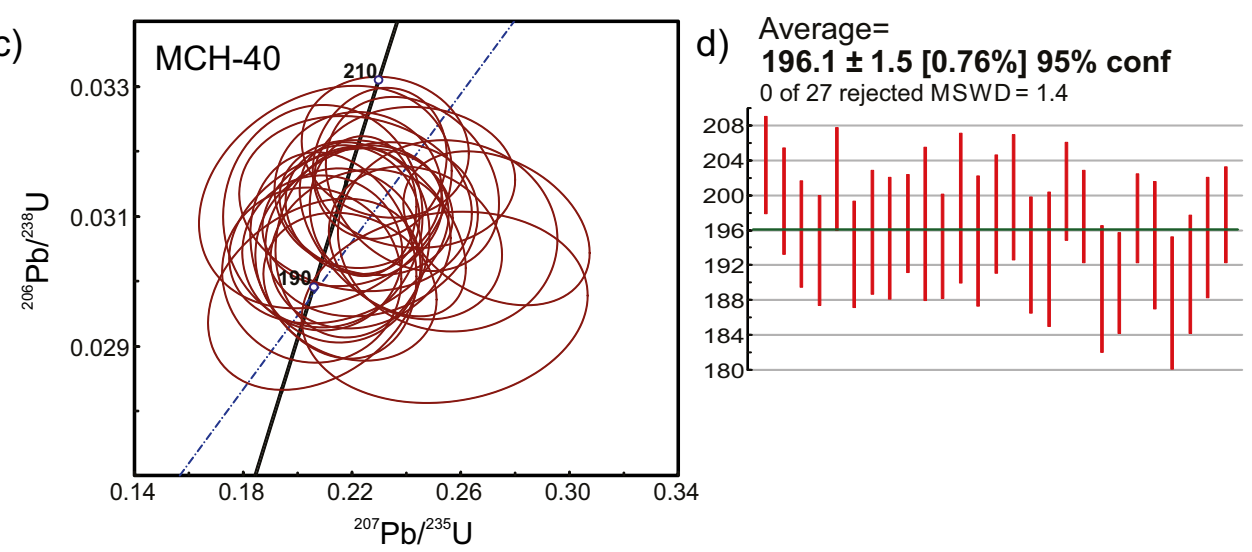

Figure 3. U-Pb Concordia diagrams (Wetherill, 1956) and weighted average ${ }^{206} \mathrm{~Pb} /{ }^{238} \mathrm{U}$ age plots of zircons from samples $\mathrm{MCH}-17$ (a and b, respectively), and MCH-40 (c and d, respectively). Blue bars correspond to rejected data.

a mean of 127 ppm and SD of 21.8 (Supplementary Appendix A2). A high MSWD of 9.89 incorporates a large uncertainty, derived from quite scattered apatite $\mathrm{U}-\mathrm{Pb}$ results as well as from small age errors (Supplementary Appendix A2; Figure 4b).

The age determined in this work by apatite $\mathrm{U}-\mathrm{Pb}$ dating, lies between the zircon $\mathrm{U}-\mathrm{Pb}$ age of $115 \pm 4(2 \sigma)$ and the biotite $\mathrm{K}$-Ar age of $102.2 \pm 1.2(2 \sigma) \mathrm{Ma}$, which were previously obtained for the same granite sample by Torres de León (2016). Central values decrease systematically depending on the closure temperatures for each system; from U-Pb in zircon $\left(900\right.$ to $800{ }^{\circ} \mathrm{C}$; Lee et al., 1997; Cherniak and Watson, 2001) through $\mathrm{U}-\mathrm{Pb}$ in apatite $\left(\mathrm{ca} .450-550{ }^{\circ} \mathrm{C}\right.$; Schoene and Bowring, 2007; Chew et al., 2014; Cochrane et al., 2014) to K-Ar in biotite ( 300 to $350^{\circ} \mathrm{C}$; e.g., Faure and Mensing, 2005). On the basis of these available data, a cooling rate of $\sim 41^{\circ} \mathrm{C} / \mathrm{Ma}$ can be calculated for the magmatic system from which OV-0421 was formed. This cooling rate could be significant for the whole Tres Sabanas pluton, located in Guatemala.

\section{Sample $\mathrm{MCH}-40$}

Apatite crystals extracted from MCH-40 (Sinemurian andesite) fall towards the upper intercept in the T-W Concordia (Figure 4c). A total of 43 dated apatite crystals define a lower intercept of $198 \pm 18$ $(2 \sigma) \mathrm{Ma}$, yielding an MSWD value of 1.15 . The tendency towards the upper intercept in T-W and a large age error of $9.1 \%$ at $2 \mathrm{SE}$ are apparently linked to very low $U$ concentrations in those apatites, which range between 4.3 and $16.6 \mathrm{ppm}$ with a mean value of $7.2 \mathrm{ppm}$ and SD of 2.4 (see details in Supplementary Appendix A2).

Zircons and apatite from MCH-40 yield similar U-Pb ages of 196.1 $\pm 1.5 \mathrm{Ma}$ and $198 \pm 18(2 \sigma) \mathrm{Ma}$, respectively (Figures $3 \mathrm{~d}$ and $4 \mathrm{c}$ ). In theory, volcanic or subvolcanic samples like this andesite (or shallow plutons) should yield equivalent crystallization ages independently of the isotopic system applied. Considering that this magma cooled (crystallized) very rapidly, both those U-Pb ages can be interpreted as corresponding to the igneous crystallization age during the Sinemurian Stage. There is a large difference in the age error between the zircon $\mathrm{U}-\mathrm{Pb}$ and the apatite $\mathrm{U}-\mathrm{Pb}$ results, which is basically controlled by the strong differences in the abundance of their parent and daughter nuclides (i.e., zircon contains almost no common $\mathrm{Pb}$ and is significantly more enriched in $\mathrm{U}$ and radiogenic $\mathrm{Pb}$ when compared to apatite). It is important to note that Sinemurian igneous ages from Jurassic magmatic rocks and volcaniclastic units (Andesita Pueblo Viejo and La Silla Formation), distributed in the Chiapas Massif area, have also been detected in recent works based on U-Pb, Ar-Ar, and fission-track dating (Godínez-Urban et al., 2011; Abdullin et al., 2018).

\section{Sample MCH-17}

Non-leached apatite of sample MCH-17, dated by ID-TIMS, yielded a reversely discordant ${ }^{206} \mathrm{~Pb} /{ }^{238} \mathrm{U}$ age of $253.5 \pm 2.7(1 \sigma) \mathrm{Ma}$ (-8.9\% of discordance; Table 2; Figure 5). The negative discordance can indicate that these crystals include non-radiogenic $\mathrm{Pb}$ in their outermost zones. The leached aliquot, however, yielded a concordant ${ }^{206} \mathrm{~Pb} /{ }^{238} \mathrm{U}$ age of $247.1 \pm 0.8 \mathrm{Ma}$ with a very small $1 \sigma$-error $(0.3 \%$; Figure 5; Table 2). The results of this single exercise demonstrate that for some samples, such as $\mathrm{MCH}-17$, a rapid acid leaching may be required to remove possible superficial $\mathrm{Pb}$ contamination of non-radiogenic origin (e.g., in apatite from weathered rocks).

Using single-spot analyses performed on 39 apatites by LAICP-MS, a lower intercept U-Pb age of $243 \pm 12(2 \sigma ; 4.9 \%)$ Ma was obtained for the same sample (MSWD $=1.7$; Figure $4 \mathrm{~d}$ ), a value that agrees very well with the ID-TIMS-derived concordant $\mathrm{U}-\mathrm{Pb}$ age of 
a)
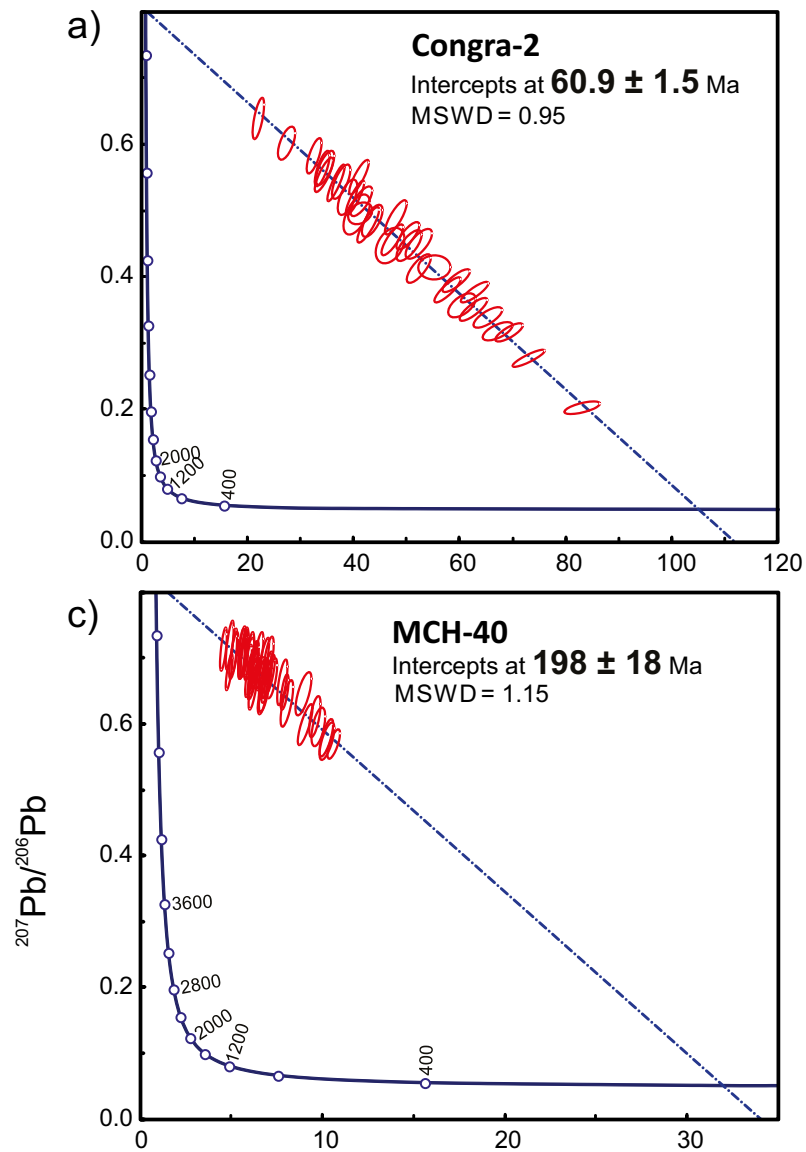

e)

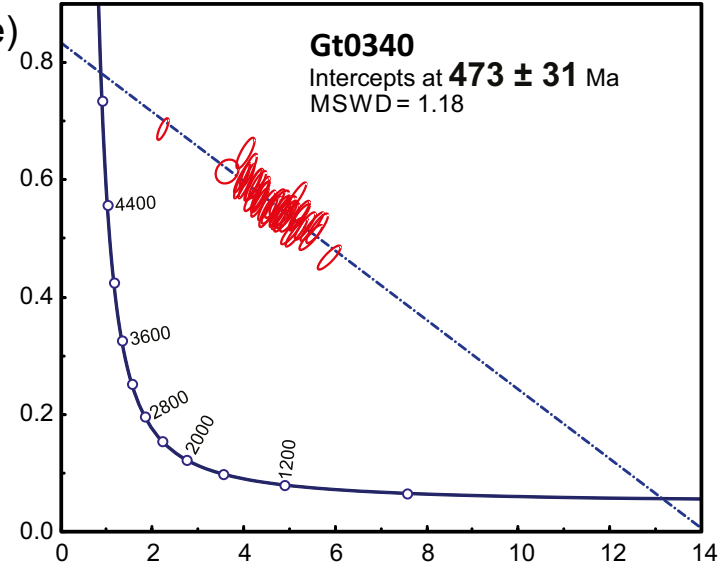

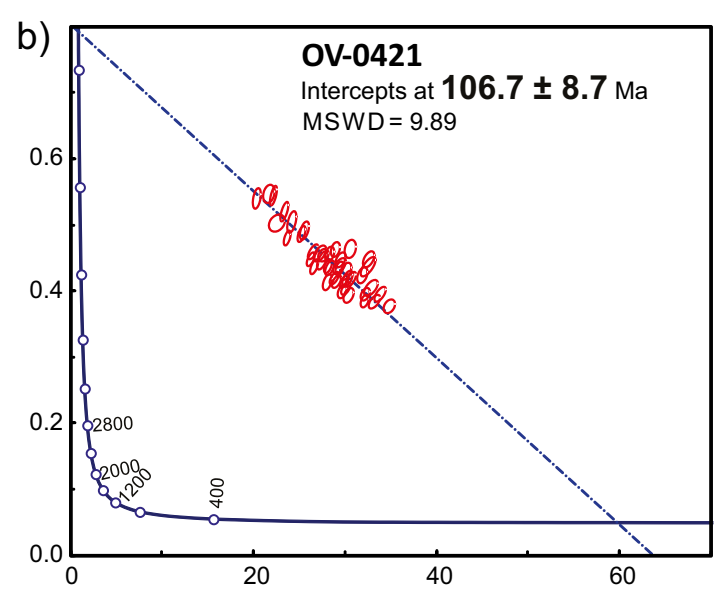

d)
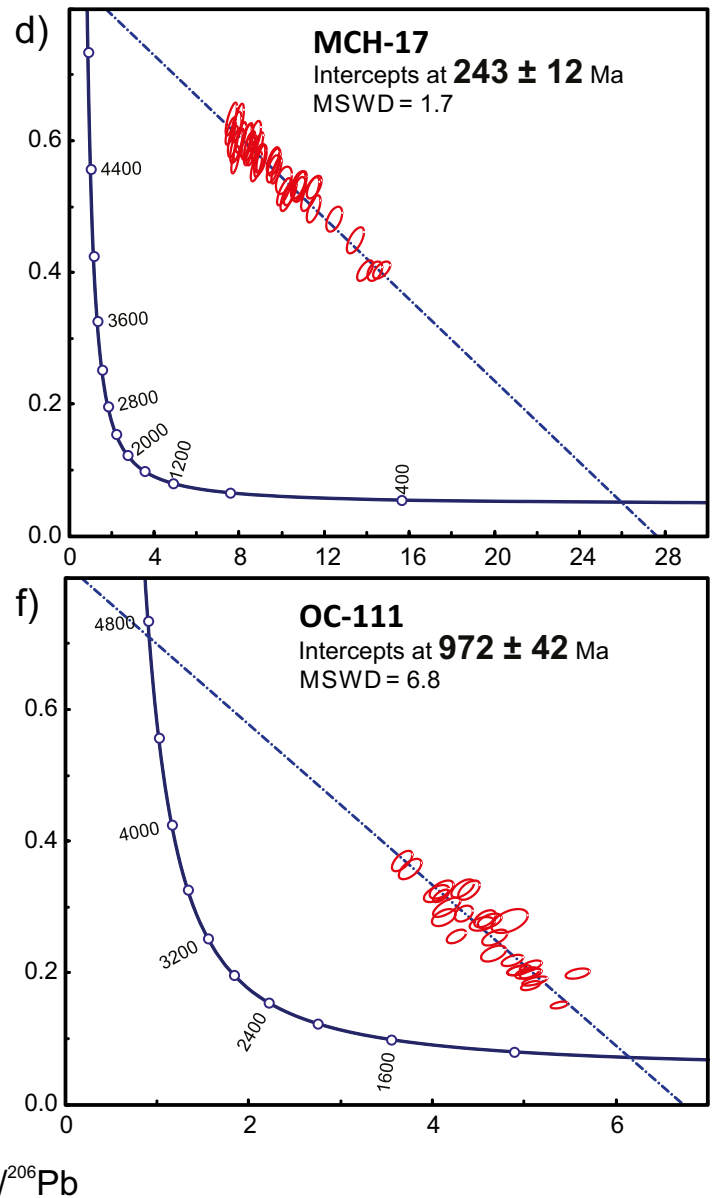

Figure 4. Tera-Wasserburg Concordia diagrams for U-Pb data of apatites from samples: (a) Congra-2; (b) OV-0421; (c) MCH-40; (d) MCH-17; (e) GT-0340; and, (f) OC-111.

$247.1 \pm 0.8 \mathrm{Ma}(1 \sigma)$.In these apatites $U$ vary from 11.5 to $34.7 \mathrm{ppm}$, giving a mean concentration of $18.7 \mathrm{ppm}$ with a SD of 6.1 (Supplementary Appendix A2).

Both apatite $\mathrm{U}-\mathrm{Pb}$ dates of $247.1 \pm 0.8(1 \sigma) \mathrm{Ma}$ and $243 \pm 12(2 \sigma)$ Ma obtained for sample MCH-17 by two different analytical techniques are younger than (or, within the analytical uncertainty of) the zircon crystallization age of $253 \pm 2.5(2 \sigma)$ Ma (Figures $3 \mathrm{~b}, 4 \mathrm{~d}$, and 5). In general, our $\mathrm{U}-\mathrm{Pb}$ results are in close agreement with geochronological data reported for the Chiapas Massif in previous studies (Damon et al., 1981; Schaaf et al., 2002; Weber et al., 2005). For example, K-Ar biotite ages compiled by Torres et al. (1999) mostly lie within the Early Triassic. Triassic cooling ages from the Chiapas Massif were also detected by Rb-Sr in mica-whole rock pairs that range from $244 \pm 12$ to $214 \pm 11(2 \sigma) \mathrm{Ma}$ (Schaaf et al., 2002). Therefore, our apatite U-Pb ages suggest that the main post-emplacement thermal cooling of the Chiapas Massif started during the earliest Triassic.

\section{Sample GT-0340}

A total of 37 apatite crystals analyzed from the Rabinal Granite GT0340 yielded a lower intercept age of $473 \pm 31(2 \sigma ; \sim 6.6 \%) \mathrm{Ma}$ (Figure 
Table 2. U-Pb isotopic results by ID-TIMS of leached and unleached apatite from sample MCH-17.

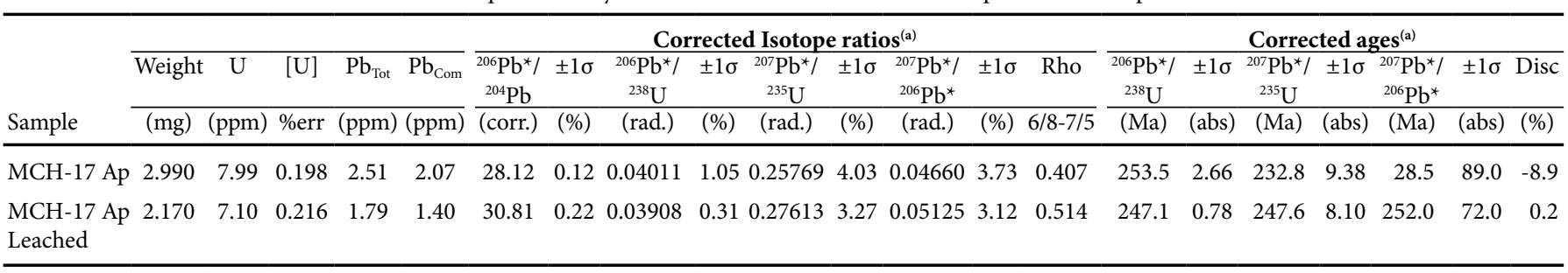

${ }^{*}$ Denotes radiogenic lead; ${ }^{(a)}$ Decay constants used ${ }^{238} \mathrm{U}=1.55125{ }^{\star} 10-10 ;{ }^{235} \mathrm{U}=9.48485^{\star} 10^{-10} ;{ }^{238} \mathrm{U} /{ }^{235} \mathrm{U}=137.88$; Rho: Error correlation.

4e), and these grains display U contents between 3.1 and $124.3 \mathrm{ppm}$ with a mean of $19.6 \mathrm{ppm}$ and SD of 19 (see Supplementary Appendix A2). The MSWD of 1.18 suggests that all dated apatites pertain to a single age population. The apatite U-Pb age of $473 \pm 31(2 \sigma) \mathrm{Ma}$ is identical within error to the Rabinal Granite emplacement age of $483 \pm$ $7(2 \sigma)$ Ma obtained for the from same rock sample (ID-TIMS-derived zircon U-Pb results, reported by Ortega-Obregón et al., 2008), indicating a shallow crystallization and fast cooling.

\section{Sample OC-111}

Finally, the gneiss sample OC-111 from the Oaxacan metamorphic complex, yielded an apatite U-Pb age of $972 \pm 42(2 \sigma)$ Ma that was obtained from only 27 grains $(\mathrm{MSWD}=6.8$; Figure $4 \mathrm{f})$. These apatites are poor in $\mathrm{U}(3.3-38.1 \mathrm{ppm}$, mean $=13.4$ and $\mathrm{SD}=6.9$; Supplementary Appendix A2); but yielded a relatively precise age due to the significant ingrowth of radiogenic $\mathrm{Pb}$, proportional to their "old" ages (Figure 4f). Therefore, some apatites from OC-111 display almost concordant ages, a behavior that was not observed for the younger samples tested (Figures 4a, 4b, 4c, 4d, 4e, and 4f). The high MSWD seems to be related to natural age dispersion (Supplementary Appendix A2; Figure 4f).

The apatite $\mathrm{U}-\mathrm{Pb}$ age of $972 \pm 42(2 \sigma)$ Ma obtained for OC-111 is within the age of the granulite facies metamorphism in the Oaxacan Complex, calculated at $990 \pm 10 \mathrm{Ma}$ (Solari et al., 2003, 2014). On the other hand, the central age is in line with a few cooling ages reported from the northern Oaxacan Complex including a titanite $\mathrm{U}-\mathrm{Pb}$ age of $968 \pm 9 \mathrm{Ma}(2 \sigma)$ and a phlogopite Ar-Ar age of $945 \pm 10(2 \sigma) \mathrm{Ma}$ (Keppie et al., 2004). Thus, all these cooling ages correspond to the

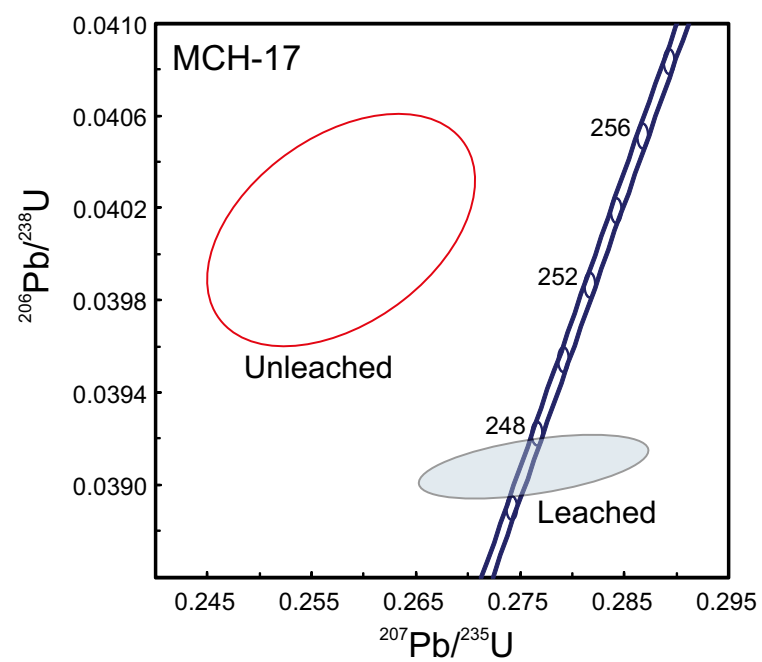

Figure 5. U-Pb Concordia plot (Wetherill, 1956) for U-Pb data of apatites from sample MCH-17 obtained with ID-TIMS. Leached aliquot in gray (filled) and unleached aliquot in red. earliest cooling period after the main metamorphic event (i.e., postmetamorphic cooling ages). It can also be proposed that the high dispersion of ages $(\mathrm{MSWD}=6.8)$ may imply that some apatites actually record the age of metamorphism at $1 \mathrm{Ga}$, whereas some others may display true cooling signals (Figure 4 f; see also detailed apatite $\mathrm{U}-\mathrm{Pb}$ results in Supplementary Appendix A2).

\section{DISCUSSION}

Medium-temperature thermochronology methods (e.g., K-Ar, Ar$\mathrm{Ar}$, or $\mathrm{Rb}-\mathrm{Sr}$ in micas, apatite $\mathrm{U}-\mathrm{Pb}$, and titanite fission-track dating) can be employed to resolve many fundamental geological problems such as to reconstruct the thermal history of ancient crystalline basements, to obtain the ages of metamorphic events and magmatic or mineralization processes, as well as for provenance analyses (e.g., Schaaf et al., 2002; Keppie et al., 2004; Schoene and Bowring, 2007; DuqueTrujillo et al., 2014; Liu et al., 2014; Bedoya et al., 2017).

Some advantages and disadvantages of ID-TIMS- and LA-ICPMS-based apatite $\mathrm{U}-\mathrm{Pb}$ methods were observed during this study and are described in the following paragraphs. ID-TIMS technique undoubtedly yields high-precision apatite $\mathrm{U}-\mathrm{Pb}$ results $(\mathrm{MCH}-17$; Table 2), and this is a critical advantage over the LA-ICP-MS-based apatite U-Pb dating. ID-TIMS, thus, is very useful in certain cases; for example, during the search for new apatite U-Pb standards, for the dating of young apatite samples with low radiogenic $\mathrm{Pb}$ contents (e.g., apatite from Rupelian-aged ore deposits and Oligocene-Miocene igneous rocks which are widespread in Mexico), as well as the dating of those rocks, in which apatite may contain extremely low $\mathrm{U}$ concentrations (e.g., many high-pressure metamorphic or some intermediate to felsic volcanic rocks; see Henrichs et al., 2018). However, there are also inconvenient points of ID-TIMS that should be outlined. First of all, ID-TIMS U-Pb is a time-consuming technique, due to numerous steps in the chemical treatment required for samples to be dated, which may generate a high analytical cost. Secondly, ID-TIMS is a totally destructive dating technique (i.e., aliquots of crystals must be digested entirely; see subsection "ID-TIMS methodology, LUGIS").

After our observations during the LA-ICP-MS experiments, for most igneous or metamorphic rock samples 40 to 60 single-spot analyses may be recommended to obtain reliable apatite $\mathrm{U}-\mathrm{Pb}$ results. There are not any significant difficulties for the dating of very old apatite samples, which in any case may contain high concentrations of radiogenic lead generated over a large geological time, and a small number of grains can be sufficient to obtain quite representative $\mathrm{U}-\mathrm{Pb}$ ages (e.g., 20-30 spots; OC-111). It is more convenient to date isotopically highly heterogeneous apatites, which may yield a perfectly aligned trend in the T-W Discordia line with a statistically very reliable $\mathrm{U}-\mathrm{Pb}$ date (e.g., see results for Congra-2). To test the heterogeneity of isotopic ratios before LA-ICP-MS sessions, a simple trial can be proposed for apatite. This can be done by etching mounted and polished apatite crystals, 
a chemical procedure commonly applied to reveal ${ }^{238} \mathrm{U}$ spontaneous fission tracks. For either magmatic or metamorphic apatite samples with monotonic cooling histories for the fission-track system, the heterogeneity of spontaneous fission track densities is directly related to the heterogeneity of $U$ distribution, and consequently may imply a strong heterogeneity of isotope ratios for the U-Pb system. This rapid test can be used to choose more convenient samples for apatite $\mathrm{U}-\mathrm{Pb}$ dating, especially for the LA-ICP-MS-based technique.

Although apatite $\mathrm{U}-\mathrm{Pb}$ ages obtained by LA-ICP-MS display larger errors than zircon U-Pb ages also obtained by LA-ICP-MS (ca. $2.5-9.1 \%$ for $2 \sigma$ level, this study, vs. ca. $2 \%$ at $2 \sigma$; e.g., Horstwood et al., 2016), which is mainly due to lower contents of $U$ and thus of radiogenic $\mathrm{Pb}$ in apatite, they are typically accurate when there has been no subsequent open system behavior and the obtained lower intercept $\mathrm{U}-\mathrm{Pb}$ ages are precise enough to be geologically meaningful. It is important to note that the statistics for apatite $\mathrm{U}-\mathrm{Pb}$ dating by LA-ICP-MS may be improved by employing a larger spot diameter (80 $\mu \mathrm{m}$ or above) combined with a longer data acquisition time (e.g., 55 seconds), as well as by changing other parameters of laser ablation and ICP-MS operation conditions.

A correct estimation of initial ${ }^{207} \mathrm{~Pb} /{ }^{206} \mathrm{~Pb}$ ratio is also very important to calculate reliable LA-ICP-MS-derived apatite U-Pb ages. There are some advantages of LA-ICP-MS over ID-TIMS. Among them, sample preparation and lower costs. The ability of LA-ICP-MS to measure also REE simultaneously with $\mathrm{U}$, Th, $\mathrm{Sr}, \mathrm{Y}, \mathrm{Mn}, \mathrm{Mg}, \mathrm{Cl}$, and isotopic ratios gives complementary information on the chemical composition of apatite that can be used for simultaneous double dating of single grains by $\mathrm{U}-\mathrm{Pb}$ plus in-situ fission-tracks, as well as for petrogenetic, metallogenetic and provenance studies. Moreover, and this is also an important advantage, LA-ICP-MS is not such destructive technique if compared to ID-TIMS; therefore, mounted crystals already analyzed by LA-ICP-MS may be repeatedly used in further microanalytical experiments.

\section{GENERAL CONCLUSIONS}

In this experimental study, we report the first apatite $\mathrm{U}-\mathrm{Pb}$ data obtained in two Mexican geochronology labs, LUGIS and LEI, both at UNAM, testing this technique on different igneous and metamorphic rocks which have already been dated by conventional radioisotopic methods like U-Pb on zircon, and $\mathrm{K}-\mathrm{Ar}$ or Ar-Ar in micas and hornblende. The obtained results agree well with the isotopic ages available for the same samples as well as for the same geological units studied. The apatite $\mathrm{U}-\mathrm{Pb}$ ages are precise enough to be meaningful, and in most of the studied cases they display the igneous crystallization age, suggesting rocks were emplaced at depths with temperature lower than the $\mathrm{Pb}$ partial retention zone. Apatite $\mathrm{U}-\mathrm{Pb}$ dating has many particular advantages as compared to other medium-temperature methods. The results of our study validate the analytical procedures employed and can undoubtedly serve as a crucial starting point towards the development and improvement of medium-temperature thermochronometry tools in Mexico.

\section{ACKNOWLEDGEMENTS}

This paper is a contribution to PAPIIT-DGAPA UNAM grant IN103417, given to LAS. Professor Stuart Thomson (University of Arizona) is acknowledged for providing several fragments of the Madagascar apatite standard. Dr. Luca Ferrari (UNAM, Centro de Geociencias) kindly provided sample Congra-2 that was important to validate the LA-ICP-MS-based apatite U-Pb method in the LEI. FA acknowledges DGAPA UNAM for a 2016-2018 postdoctoral fellowship. The authors are grateful to Juan Tomás Vázquez Ramírez, Manuel Albarrán Murillo, Oscar Aguilar Moreno, and Ofelia Pérez Arvizu (all from CGEO, Campus Juriquilla, UNAM) for their help with sample preparation. Teodoro Hernández Treviño and Gerardo Arrieta García from the LUGIS (Instituto de Geofísica, CDMX, UNAM) are also acknowledged for their help with TIMS measurements. We want also to thank two anonymous reviewers that help to improve this paper.

\section{SUPPLEMENTARY MATERIAL}

Supplementary Appendix A1 "Zircon U-Pb corrected isotopes and ages of samples analyzed by LA-ICP-MS" and Supplementary Appendix A2 "Apatite $\mathrm{U}-\mathrm{Pb}$ corrected isotopes and ages of samples analyzed by LA-ICP-MS" can be found at the journal web site $<$ http://rmcg.unam. $\mathrm{mx} />$, in the table of contents of this issue.

\section{REFERENCES}

Abdullin, F., Solé, J., Solari, L., 2014, Datación mediante trazas de fisión y análisis multielemental con LA-ICP-MS del fluorapatito de Cerro de Mercado (Durango, México): Revista Mexicana de Ciencias Geológicas, 31(3), 395-406.

Abdullin, F., Solé, J., Meneses-Rocha, J.J., Solari, L., Shchepetilnikova V., OrtegaObregón C., 2016a, LA-ICP-MS-based apatite fission track dating of the Todos Santos Formation sandstones from the Sierra de Chiapas (SE Mexico) and its tectonic significance: International Geology Review, 58(1), 32-48. https://doi.org/10.1080/00206814.2015.1055596.

Abdullin, F., Solé, J., Solari, L., Shchepetilnikova, V., Meneses-Rocha, J.J., Pavlinova, N., Rodríguez-Trejo, A., 2016b, Single-grain apatite geochemistry of Permian-Triassic granitoids and Mesozoic and Eocene sandstones from Chiapas, southeast Mexico: implications for sediment provenance: International Geology Review, 58(9), 1132-1157.

Abdullin, F., Solari, L., Ortega-Obregón, C., Solé, J., 2018, New fission-track results from the northern Chiapas Massif area, SE Mexico: trying to reconstruct its complex thermo-tectonic history: Revista Mexicana de Ciencias Geológicas, 35(1), 79-92.

Bedoya, A., Abdullin, F., Solari, L., 2017, Uso de apatitos para trazar procesos de procedencia y exhumación: un ejemplo de las cuencas Paleozoicas del Sur de México, in Reunión Anual UGM: Puerto Vallarta, Mexico, libro de resúmenes, resumen número 0437.

Belousova, E.A., Griffin, W.L., O’Reilly, S.Y., Fisher, N.I., 2002, Apatite as an indicator mineral for mineral exploration: trace-element compositions and their relationship to host rock type: Journal of Geochemical Exploration, 76(1), 45-69.

Bizzarro, M., Simonetti, A., Stevenson, R.K., Kurszlaukis, S., 2003, In situ ${ }^{87} \mathrm{Sr} /{ }^{86} \mathrm{Sr}$ investigation of igneous apatites and carbonates using laser-ablation $\mathrm{MC}$ ICP-MS: Geochimica et Cosmochimica Acta, 67(2), 289-302.

Bruand, E., Storey, C., Fowler, M., 2016, An apatite for progress: Inclusions in zircon and titanite constrain petrogenesis and provenance: Geology, 44(2), 91-94.

Castro-Mora, J.T., Schlaepfer, C.J., Rodríguez E.M., 1975, Estratigrafía y microfacies del Mesozoico de la Sierra de Madre del Sur, Chiapas: Boletín de la Asociación Mexicana de Geólogos Petroleros, 27(1-3), 1-39 + 31 plates.

Chamberlain, K.R., Bowring, S.A., 2001, Apatite-feldspar U-Pb thermochronometer: a reliable, mid-range $\left(\sim 450^{\circ} \mathrm{C}\right)$, diffusion-controlled system: Chemical Geology, 172(1), 173-200.

Cherniak, D.J., Watson, E.B., 2001, Pb diffusion in zircon: Chemical Geology, 172(1), 5-24.

Cherniak, D. J., Lanford, W. A., Ryerson, F. J., 1991, Lead diffusion in apatite and zircon using ion implantation and Rutherford Backscattering techniques: Geochimica et Cosmochimica Acta, 55(6), 1663-1673, https://doi org/10.1016/0016-7037(91)90137-T. 
Chew, D.M., Donelick, R.A., 2012, Combined apatite fission-track and U-Pb dating by LA-ICP-MS and its application in apatite provenance analysis, in Sylvester, P. (ed.), Quantitative Mineralogy and Microanalysis of Sediments and Sedimentary Rocks: Mineralogical Association of Canada, Short Course 42, 219-247.

Chew, D.M., Sylvester, P.J., Tubrett, M.N., 2011, U-Pb and Th-Pb dating of apatite by LA-ICPMS: Chemical Geology, 280(1), 200-216.

Chew, D.M., Petrus, J.A., Kamber, B.S., 2014, U-Pb LA-ICPMS dating using accessory mineral standards with variable common $\mathrm{Pb}$ : Chemical Geology, 363, 185-199.

Cochrane, R., Spikings, R.A., Chew, D., Wotzlaw, J.F., Chiaradia, M., Tyrrell, S., van der Lelij, R., 2014, High temperature $\left(>350^{\circ} \mathrm{C}\right)$ thermochronology and mechanisms of $\mathrm{Pb}$ loss in apatite: Geochimica et Cosmochimica Acta, 127, 39-56.

Copeland, P., Parrish, R.R., Harrison, T.M., 1988, Identification of inherited radiogenic $\mathrm{Pb}$ in monazite and implications for $\mathrm{U}-\mathrm{Pb}$ systematics: Nature 333, 760-763.

Damon, P.E., Shafiqullah, M., Clark, K.F., 1981, Age trends of igneous activity in relation to metallogenesis in the southern Cordillera, in William, R.D., William, D.P. (eds.), Relations of Tectonics to Ore Deposits in the Southern Cordillera: Tucson, Arizona, Arizona Geological Society Digest, 14, 137-153.

Dodson, M.H., 1973, Closure temperature in cooling geochronological and petrological systems: Contributions to Mineralogy and Petrology, 40, 259-274.

Donelick, R.A., O’Sullivan, P.B., Ketcham, R.A., 2005, Apatite fission-track analysis: Reviews in Mineralogy and Geochemistry, 58(1), 49-94.

Duque-Trujillo, J., Ferrari, L., Orozco-Esquivel, T., López-Martínez, M., Lonsdale, P., Bryan, S.E., Kluesner, J., Piñero-Lajas, D., Solari, L., 2014, Timing of rifting in the southern Gulf of California and its conjugate margins: Insights from the plutonic record: Geological Society of America Bulletin, 127(5-6), 702-736, https://doi.org/10.1130/B31008.1.

Ehlers, T.A., Farley, K.A., 2003, Apatite (U-Th)/He thermochronometry: methods and applications to problems in tectonic and surface processes: Earth and Planetary Science Letters, 206(1), 1-14.

Elías-Herrera, M., Ortega-Gutiérrez, F., Sánchez-Zavala, J.L., Macías-Romo, C. Ortega-Rivera, A., Iriondo, A., 2007, The Caltepec fault zone: Exposed roots of a long-lived tectonic boundary between two continental terranes of southern México: Geological Society of America Special Papers, 422, 317-342.

Enkelmann, E., Ridgway, K.D., Carignano, C., Linnemann, U., 2014, A thermochronometric view into an ancient landscape: tectonic setting, development, and inversion of the Paleozoic eastern Paganzo basin Argentina: Lithosphere, 6(2), 93-107.

Faure, G., Mensing, T.M., 2005, Isotopes: Principles and applications: New York, John Wiley \& Sons, 897 pp.

Gehrels, G.E., Valencia, V.A., Ruiz, J., 2008, Enhanced precision, accuracy, efficiency, and spatial resolution of $\mathrm{U}-\mathrm{Pb}$ ages by laser ablationmulticollector-inductively coupled plasma-mass spectrometry: Geochemistry Geophysics Geosystems, 9(3), Q03017, http://doi. org/10.1029/2007GC001805.

Godínez-Urban, A., Lawton, T.F., Garza, R.S.M., Iriondo, A., Weber, B., López-Martínez, M., 2011, Jurassic volcanic and sedimentary rocks of the La Silla and Todos Santos Formations, Chiapas: Record of Nazas arc magmatism and rift-basin formation prior to opening of the Gulf of Mexico: Geosphere, 7(1), 121-144.

Green, T.H., Watson, E.B., 1982, Crystallization of apatite in natural magmas under high pressure, hydrous conditions, with particular reference to 'Orogenic' rock series: Contributions to Mineralogy and Petrology, (79), 96-105.

Hasebe, N., Barbarand, J., Jarvis, K., Carter, A., Hurford, A.J., 2004, Apatite fission-track chronometry using laser ablation ICP-MS: Chemical Geology, 207(3), 135-145.

Henrichs, I.A., O’Sullivan, G., Chew, D.M., Mark, C., Babechuk, M.G., McKenna C., Emo, R., 2018, The trace element and U-Pb systematics of metamorphic apatite: Chemical Geology, 483, 218-238.

Horstwood, M.S.A., Košler, J., Gehrels, G., Jackson, S.E., McLean, N.M., Paton, C., Pearson, N., Sircombe, K., Sylvester, P., Vermeesch, P., Bowring, J.F., Condon, D.J., Schoene B., 2016, Community-Derived Standards for
LA-ICP-MS U-Th-Pb Geochronology - Uncertainty Propagation, Age Interpretation and Data Reporting: Geostandards and Geoanalytical Research, 40(3), 311-332, http://doi.org/10.1111/j.1751-908X.2016.00379.

Jackson, S.E., Pearson, N.J., Griffin, W.L., Belousova, E.A., 2004, The application of laser ablation-inductively coupled plasma-mass spectrometry to in situ U-Pb zircon geochronology: Chemical Geology, 211(1-2), 47-69, https:// doi.org/10.1016/j.chemgeo.2004.06.017

Jafarzadeh, M., Harami, R.M., Friis, H., Amini, A., Mahboubi, A., Lenaz, D., 2014, Provenance of the Oligocene-Miocene Zivah Formation, NW Iran, assessed using heavy mineral assemblage and detrital clinopyroxene and detrital apatite analyses: Journal of African Earth Sciences, 89, 56-71.

Keppie, J.D., Solari, L.A., Ortega-Gutiérrez, F., Ortega-Rivera, A., Lee, J.K., Lopez, R., Hames, W.E., 2004, U-Pb and ${ }^{40} \mathrm{Ar} /{ }^{39} \mathrm{Ar}$ constraints on the cooling history of the northern Oaxacan Complex, southern Mexico: Tectonic implications: Geological Society of America Memoirs 197, 771-781.

Košler, J., Fonneland, H., Sylvester, P., Tubrett, M., Pedersen, R.B., 2002, U-Pb dating of detrital zircons for sediment provenance studies-a comparison of laser ablation ICPMS and SIMS techniques: Chemical Geology, 182(24), 605-618

Krogh, T., 1982, Improved accuracy of U-Pb zircon ages by the creation of more concordant systems using an air abrasion technique: Geochimica et Cosmochimica Acta, 46(4), 637-649.

Lee, J.K.W., Williams, I.S., Ellis, D.J., 1997, Pb, U and Th diffusion in natural zircon: Nature, 390 (6656), 159-162.

Lesnov, F.P., 2012, Rare Earth Elements in Ultramafic and Mafic Rocks and their Minerals, Minor and accessory minerals: London, UK, Taylor and Francis Group, 314 pp.

Liu, W., Zhang, J., Sun, T., Wang, J., 2014, Application of apatite U-Pb and fission-track double dating to determine the preservation potential of magnetite-apatite deposits in the Luzong and Ningwu volcanic basins, eastern China: Journal of Geochemical Exploration, 138, 22-32.

Ludwig, K.R., 1993, PBDAT, A Computer Program for Processing Pb-U-Th Isotope Data, Version 1.24: United States Geological Survey, Open-File Report, 88-542.

Ludwig, K.R., 2008, Isoplot/Ex, ver. 3.7, A Geochronological Toolkit for Microsoft Excel: Berkeley Geochronology Center, Special Publication 4, $76 \mathrm{pp}$.

Meneses-Rocha, J.J., 2001, Tectonic evolution of the Ixtapa Graben, an example of a strike-slip basin of southeastern Mexico: Implications for regional petroleum systems, in Bartolini, C., Buffler, R.T., Cantú-Chapa, A. (eds.), The western Gulf of Mexico basin: Tectonics, sedimentary basins and petroleum systems: American Association of Petroleum Geologists Memoir, 75, 183-216.

Miles, A.J., Graham, C.M., Hawkesworth, C.J., Gillespie, M.R., Hinton, R.W., Bromiley, G.D., 2014, Apatite: A new redox proxy for silicic magmas?: Geochimica Et Cosmochimica Acta, 132, 101-119.

Morton, A.C., Hallsworth, C., 2007, Stability of detrital heavy minerals during burial diagenesis: Developments in Sedimentology, 58, 215-245.

Morton, A., Yaxley, G., 2007, Detrital apatite geochemistry and its application in provenance studies: Geological Society of America Special Papers, 420, 319-344.

O’Sullivan, G.J., Chew, D.M., Samson, S.D., 2016, Detecting magma-poor orogens in the detrital record: Geology, 44(10), 871-874.

Ortega-Obregón, C., Solari, L.A., Keppie, J.D., Ortega-Gutiérrez, F., Solé, J., Morán-Ical, S., 2008, Middle-Late Ordovician magmatism and Late Cretaceous collision in the southern Maya block, Rabinal-Salamá area, central Guatemala: implications for North America-Caribbean plate tectonics: Geological Society of America Bulletin, 120(5-6), 556-570.

Ortega-Obregón, C., Solari, L., Gómez-Tuena, A., Elías-Herrera, M., OrtegaGutiérrez, F., Macías-Romo, C., 2014, Permian-Carboniferous arc magmatism in southern Mexico: $\mathrm{U}-\mathrm{Pb}$ dating, trace element and $\mathrm{Hf}$ isotopic evidence on zircons of earliest subduction beneath the western margin of Gondwana: International Journal of Earth Sciences, 103(5), 1287-1300.

Paton, C., Hellstrom, J., Paul, B., Woodhead, J., Hergt, J., 2011, Iolite: Freeware for the visualisation and processing of mass spectrometric data: Journal of Analytical Atomic Spectrometry, 26(12), 2508-2518.

Petrus, J.A., Kamber, B.S., 2012, VizualAge: A novel approach to laser ablation 
ICP-MS U-Pb geochronology data reduction: Geostandards and Geoanalytical Research, 36(3), 247-270.

Piccoli, P.M., Candela, P.A., 2002, Apatite in igneous systems: Reviews in Mineralogy and Geochemistry, 48, 255-292.

Schaaf, P., Weber, B., Weis, P., Gro $\beta$, A., Ortega-Gutiérrez, F., Kohler, H., 2002, The Chiapas Massif (Mexico) revised: New geologic and isotopic data and basement characteristics, in Miller, H.E., (ed.), Contributions to LatinAmerican Geology: Neues Jahrbuch für Geologie und Paläontologie, Abhandlungen, 225, 1-23.

Schoene, B., 2014, U-Th-Pb Geochronology, Ch. 4.10, in Holland, H.D., Turekian, K.K. (eds.) Treatise on Geochemistry: Elsevier, 341-378.

Schoene, B., Bowring, S.A., 2007, Determining accurate temperature-time paths from $\mathrm{U}-\mathrm{Pb}$ thermochronology: An example from the Kaapvaal craton, southern Africa: Geochimica et Cosmochimica Acta, 71(1), 165-185.

Sláma, J., Košler, J., Condon, D.J., Crowley, J.L., Gerdes, A., Hanchar, J.M., et al., 2008, Plešovice zircon - a new natural reference material for $\mathrm{U}-\mathrm{Pb}$ and $\mathrm{Hf}$ isotopic microanalysis: Chemical Geology, 249(1), 1-35.

Solari, L., Keppie, J.D, Ortega-Gutiérrez, F., Cameron, K., Lopez, R., Hames, W., 2003, 990 and $1100 \mathrm{Ma}$ Grenvillian tectonothermal events in the northern Oaxacan Complex, southern Mexico: roots of an orogeny: Tectonophysics, 365(1-4), 257-282.

Solari, L.A., Gómez-Tuena, A., Bernal, J.P., Pérez-Arvizu, O., Tanner, M., 2010, U-Pb Zircon Geochronology with an Integrated LA-ICP-MS Microanalytical Workstation: Achievements in Precision and Accuracy: Geostandards and Geoanalytical Research, 34(1), 5-18.

Solari, L.A., Garcia-Casco, A., Martens, U., Lee, J.K.W., Ortega-Rivera, A. 2013, Late Cretaceous subduction of the continental basement of the Maya block (Rabinal Granite, central Guatemala): Tectonic implications for the geodynamic evolution of Central America: Geological Society of America Bulletin, 125(3-4), 625-639, http://doi.org/10.1130/B30743.1

Solari, L.A., Ortega-Gutiérrez, F., Elías-Herrera, M., Ortega-Obregón, C., Macías-Romo, C., Reyes-Salas, M., 2014, Detrital provenance of the Grenvillian Oaxacan Complex, southern Mexico: a zircon perspective: International Journal of Earth Sciences, 103(5), 1301-1315.

Solari, L.A., Ortega-Obregón, C., Bernal, J.P., 2015, U-Pb zircon geochronology by LAICPMS combined with thermal annealing: Achievements in precision and accuracy on dating standard and unknown samples: Chemical Geology, 414, 109-123.

Solé, J., Pi, T., 2005, An empirical calibration for ${ }^{4} \mathrm{He}$ quantification in minerals and rocks by laser fusion and noble gas mass spectrometry using Cerro de Mercado (Durango, Mexico) fluorapatite as a standard: Analytica Chimica Acta, 535(1-2), 325-330.

Spikings, R., Cochrane, R., Villagomez, D., van der Lelij, R., Vallejo, C., Winkler, W., Beate, B., 2015, The geological history of northwestern South America: From Pangaea to the early collision of the Caribbean large igneous province (290-75 Ma): Gondwana Research, 27(1), 95-139.

Stacey, J.T., Kramers, 1975, Approximation of terrestrial lead isotope evolution by a two-stage model: Earth and Planetary Science Letters, 26(2), 207-221.
Tera, F., Wasserburg, G., 1972, U-Th-Pb systematics in three Apollo 14 basalts and the problem of initial $\mathrm{Pb}$ in lunar rocks: Earth and Planetary Science Letters, 14, 281-304.

Thomson, S.N., Gehrels, G.E., Ruiz, J., Buchwaldt, R., 2012, Routine lowdamage apatite $\mathrm{U}-\mathrm{Pb}$ dating using laser ablation-multicollector-ICPMS: Geochemistry, Geophysics, Geosystems, 13(2).

Torres, R., Ruiz, J., Patchett, P.J., Grajales, J.M., 1999, Permo-Triassic continental arc in eastern Mexico: Tectonic implications for reconstructions of southern North America: Geological Society of America, Special Paper $340,191-196$

Torres de León, R., 2016, Caracterización geológica y geocronológica de unidades metamórficas e intrusivas de la región centro-Oeste de la Cuenca del Río Motagua, Sureste de Guatemala, Centroamérica: implicaciones en las conexiones Sur de México-Bloque Chortis: Mexico, Universidad Nacional Autónoma de México, Posgrado en Ciencias de la Tierra, Ph. D. Thesis, $221 \mathrm{pp}$.

Villa, I.M., 1988, Isotopic closure: Terra Nova, 10, 42-47.

Weber, B., Cameron, K.L., Osorio, M., Schaaf, P., 2005, A late Permian tectonothermal event in Grenville crust of the southern Maya terrane: $\mathrm{U}-\mathrm{Pb}$ zircon ages from the Chiapas Massif, southeastern Mexico: International Geology Review, 47, 509-529.

Weber, B., Iriondo, A., Premo, W.R., Hecht, L., Schaaf, P., 2007, New insights into the history and origin of the southern Maya block, SE México: $\mathrm{U}-\mathrm{Pb}-$ SHRIMP zircon geochronology from metamorphic rocks of the Chiapas massif: International Journal of Earth Sciences, 96, 253-269.

Weber, B., Valencia, V.A., Schaaf, P., Pompa-Mera, V., Ruiz, J., 2008, Significance of Provenance Ages from the Chiapas Massif Complex (Southeastern Mexico): Redefining the Paleozoic Basement of the Maya Block and Its Evolution in a Peri-Gondwanan Realm: The Journal of Geology, 116, 619-639.

Webster, J.D., Piccoli, P.M., 2015, Magmatic apatite: A powerful, yet deceptive, mineral: Elements, 11, 177-182.

Wetherill, G.W., 1956, Discordant uranium-lead ages: I. EOS, Transactions American Geophysical Union, 37(3), 320-326.

Wiedenbeck, M., Alle, P., Corfu, F., Griffin, W.L., Meier, M., Oberli, F., Spiegel, W., 1995, Three natural zircon standards for U-Th-Pb, Lu-Hf, trace element and REE analyses: Geostandards Newsletter, 19(1), 1-23.

Wiedenbeck, M., Hanchar, J.M., Peck, W.H., Sylvester, P., Valley, J., Whitehouse, M., Franchi, I., 2004, Further characterization of the 91500 zircon crystal: Geostandards and Geoanalytical Research, 28(1), 9-39.

Wolf, R.A., Farley, K.A., Silver, L.T., 1996, Helium diffusion and low-temperature thermochronometry of apatite: Geochimica et Cosmochimica Acta, 60(21), 4231-4240.

Manuscript received: february 20, 2018

Corrected manuscript received: october 21, 2018

Manuscript accepted: october 22, 2018 